\title{
AGES OF SEDIMENTATION OF THE KINZIGITIC COMPLEX AND OF A LATE OROGENIC THERMAL EPISODE IN THE ARAÇUAÍ OROGEN, NORTHERN ESPÍRITO SANTO STATE, BRAZIL: ZIRCON AND MONAZITE U-PB SHRIMP AND ID- TIMS DATA
}

\section{CARLOS MAURICIO NOCE ${ }^{1}$, ANTÔNIO CARLOS PEDROSA-SOARES ${ }^{1}$, DANIELLE PIUZANA ${ }^{1}$, RICHARD ARMSTRONG ${ }^{2}$, JORGE HENRIQUE LAUX ${ }^{3}$, CRISTINA MARIA DE CAMPOS $^{4} \&$ SÍLVIA REGINA DE MEDEIROS3 ${ }^{3}$}

\begin{abstract}
Resumo IDADES DA SEDIMENTAÇÃO DO COMPLEXO KINZIGÍTICO E DE UM EPISÓDIO TERMAL TARDIO NO ORÓGENO ARAÇUAÍ, NORTE DO ESPIRITO SANTO, BRASIL: DADOS U-PB SHRIMP E ID-TIMS DE ZIRCÃO E MONAZITA O complexo kinzigítico (também chamado Complexo Jequitinhonha ou Paraíba do Sul), composto principalmente de paragnaisses da fácies anfibolito alto, é uma unidade-chave para o entendimento da evolução do Orógeno Araçuaí. O complexo mostra muitas evidências de distintos episódios anatéticos. Um episódio anatético sin-cinemático à foliação regional é representado por veios quartzo-feldspáticos e corpos graníticos tipo S, foliados, originados durante o estágio sincolisional do orógeno ( $c a$. 585-560 Ma). Mobilizados graníticos livres da foliação regional registram pelo menos um episódio anatético tardi-orogênico. Cristais de zircão detríticos forneceram dados $\mathrm{U}-\mathrm{Pb}$ (SHRIMP) que indicam fontes de diferentes idades, $631 \pm 19 \mathrm{Ma}, 774 \pm 13 \mathrm{Ma}$ e $2104 \pm 12 \mathrm{Ma}$, para protólitos sedimentares do complexo kinzigítico do norte do Espírito Santo. A idade média ${ }^{207} \mathrm{~Pb} /{ }^{206} \mathrm{Pbdos}$ zircões detríticos mais jovens, limita a idade máxima de deposição destes protólitos sedimentares em $\mathrm{ca}$. $631 \mathrm{Ma}$. A fonte mais provável éo arco magmático pré-colisional do Orogéno Araçuaí. Isto sugere que o complexo kinzigítico do norte do Espírito Santo representa uma bacia retroarco. Cristais de monazita neoformados foram selecionados para análise U-Pb (ID-TIMS). Três cristais alinham-se em uma discórdia com intercepto superior em $530 \pm 5 \mathrm{Ma}$. A idade da monazita neoformada indica a época de episódio térmico tardi-orogênico, provavelmente relacionado ao início do colapso gravitacional do Orógeno Araçuaí.
\end{abstract}

Palavras-chave: complexo kinzigítico, Orógeno Araçuaí, zircão detrítico, monazita

\begin{abstract}
The kinzigitic (also called Jequitinhonha or Paraíba do Sul) complex, mainly composed of high-amphibolite facies paragneisses, is a key unit to understand the evolution of the Araçuaí Orogen (southeastern Brazil). The complex shows many evidences of distinct anatectic episodes. Foliated quartz-feldspar veins and S-type granites, synkinematic to the regional foliation, record an anatectic episode related to the syncollisional stage (585-560 Ma) of the Araçuaí Orogen. Granitic mobilizates free of the regional foliation indicate at least one late orogenic episode of partial melting. The U-Pb SHRIMP data from detrital zircons indicate sources of distinct ages, $631 \pm 19 \mathrm{Ma}, 774 \pm 13 \mathrm{Ma}$ and $2104 \pm 12 \mathrm{Ma}$, for the sedimentary protoliths of the kinzigitic complex of the northern Espírito Santo State. The mean ${ }^{207} \mathrm{~Pb} /{ }^{206} \mathrm{~Pb}$ age for the youngest detrital zircons constrains the maximum age for the deposition of these sedimentary protoliths at $\mathrm{ca} .631 \mathrm{Ma}$. The most reliable source for the youngest detrital zircons is the precollisional magmatic arc of the Araçuaí Orogen. This suggests that the kinzigitic complex of the northern Espírito Santo State was deposited at a back-arc basin. Neoformed crystals of monazite were selected for U-Pb ID-TIMS analysis. Three single monazite crystals yielded a discordia upper intercept age at $530 \pm 5 \mathrm{Ma}$. The age of the neoformed monazite dates a late orogenic thermal episode, probably related to the onset of the gravitational collapse of the Araçuaí Orogen.
\end{abstract}

Keywords: kinzigite, detrital zircon, monazite, Araçuaí Orogen, Brasiliano

INTRODUCTION The Araçuaí Orogen is the northern branch of the Brasiliano orogenic system represented by the Mantiqueira Province in southeastern and southern Brazil (e.g. Cordani et al. 2000, Heilbron et al. 2004). This orogen extends over the region from the eastern edge of the São Francisco Craton to the Atlantic Ocean, between the $15^{\circ}$ and $21^{\circ} \mathrm{S}$ parallels (Pedrosa-Soares et al. 2001).

One of the largest and most intriguing unit of the Araçuaí Orogen is a paragneiss complex of kinzigitic nature, that crops out in the northeastern and eastern regions of Minas Gerais State, the southernmost region of Bahia State and northern region of Espírito Santo State (Fig. 1). The complex has been named in several ways, depending on the geographical region. It is named Jequitinhonha Complex in northeastern Minas Gerais and southern Bahia states, and Paraíba do Sul Complex in the region extending from eastern
Minas Gerais to Espírito Santo State (Pedrosa-Soares \& Wiedemann-Leonardos 2000). In geologic maps (scale 1:100,000) of the Projeto Leste, the paragneiss complex is only called by the name Paraíba do Sul (Pinto et al. 2002). In the present paper we adopt the informal designation of kinzigitic complex (Fig. 1).

The absence of precise geochronological data in the literature and the need to understand the geotectonic setting of the kinzigitic complex in the Araçuaí Orogen have encouraged us to investigate the age of sedimentation of the kinzigite protolith by means of $\mathrm{U}$ $\mathrm{Pb}$ SHRIMP analysis on detrital zircons. U-Pb dating of detrital zircons is a powerful tool for the determination of depositional ages of Precambrian clastic sedimentary rocks. It may also give useful information about sediment provenance. This method, however, has its limitations. One is that a maximum depositional age based on dates obtained from the youngest zircons may still

1-CPMTC-IGC, Universidade Federal de Minas Gerais, 31270-901, Belo Horizonte, MG. E-MAILS: noce@ufmg.br, pedrosa@igc.ufmg.br

2 - Research School of Earth Sciences, The Australian National University, Canberra, ACT 0200, Australia

3 - Instituto de Geociências, Universidade de Brasília, Brasília, DF

4 - Departamento de Geologia, Universidade Federal do Rio de Janeiro, 21941-590 Rio de Janeiro, RJ 
be substantially older than the time of sediment deposition (e.g. Nelson 2001). The present study is based on dating the small zircon population of a single sample from the kinzigitic complex. Nevertheless, it brings very useful information regarding the depositional age and tectonic environment of a significant part of the sedimentary pile included within the Araçuaí Orogen.

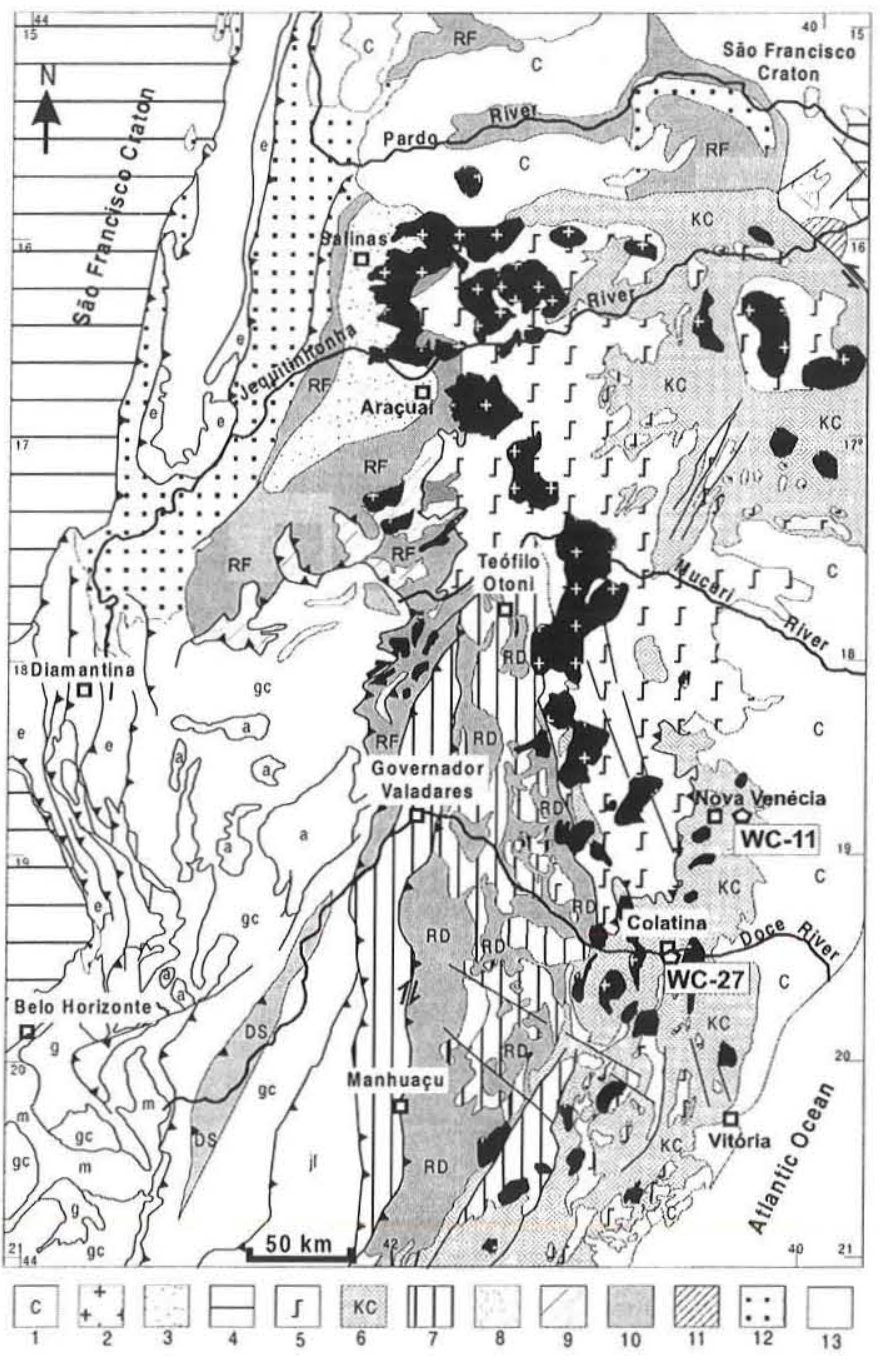

Figure 1 - Geological sketch map of the Araçuai Orogen with studied samples location (modified from Pedrosa-Soares et al. 2001 and Lima et al. 2002). 1, Cenozoic cover. 2, late-orogenic I and S-type intrusions (525-490 Ma). 3, Salinas Formation (570 Ma > age > $500 \mathrm{Ma}$ ). Neoproterozoic: 4, cratonic covers; 5 , syncollisional, S-type G2 suite (585-560 Ma) and associated late orogenic, S-type G3S suite (535-500 Ma); 6, kinzigitic complex (KZ); 7, precollisional, I-type G1 suite (630 - $585 \mathrm{Ma}$ ); 8, alkaline intrusions; 9, Capelinha Formation; 10, Ribeirão da Folha (RF), Dom Silvério (DS) and Rio Doce (RD) metavolcanosedimentary units; 11, Salto da Divisa intrusion (880 Ma); 12, proximal units of the Macaúbas Group. 13, Pre-Neoproterozoic units: gc, Archean-Paleoproterozoic gneissic complexes; $g$, Archean greenstone belt; $m$, Minas Supergroup; if, Juiz de Fora Complex; a, Borrachudos granitic suite; $e$, Espinhaço Supergroup.
We also present $\mathrm{U}-\mathrm{Pb}$ monazite data from a sample of the kinzigitic complex. Monazite is a very useful mineral to obtain ages of high temperature events that affected sedimentary deposits (e.g. Foster et al. 2000).

\section{GEOLOGIC SETTING AND PREVIOUS GEOCHRONOLOGY}

The kinzigitic complex is essentially composed of paragneisses with variable contents of peraluminous silicates, such as biotite, almandine, cordierite and sillimanite. The kinzigite stricto sensu (cf. Mehnert 1968) is the graphite-sillimanite-cordierite-garnetbiotite gneiss, a rock composed of different amounts of these peraluminous silicates associated to quartz, K-feldspar, plagioclase and traces of graphite. The kinzigite protolith is a pelite rich in the aluminous clay fraction, with minor carbonaceous material. Such paragneiss, the kinzigite, characterizes the metamorphism of pelites in the high amphibolite facies, generally accompanied by profuse partial melting. The decreasing of the Al-clay fraction and increasing of the graywacky, arcosic and/or quartzose fractions resulted in the protoliths of several varieties of paragneisses richer in quartz and feldspars and poorer in the peraluminous silicates, such as cordierite-garnet-biotite gneiss, garnet-biotite gneiss and biotite gneiss. These paragneisses are not kinzigite in the strict sense, but compose the kinzigitic rock assemblage and are called by the informal name "kinzigitic gneiss" in the study region.

The kinzigitic complex also includes layers and lenses of graphite gneiss, quartzite, sedimentary-derived calc-silicate rock, felsic granulite (leptnite), marble, and ortho-amphibolite. Considering the abundance of these subordinate rocks, the kinzigitic complex can be subdivided into three sub-units within the Araçuaí Orogen, as following:

- Sub-unit 1 is the rock assemblage of the kinzigitic complex exposed in the southern region of Espírito Santo State, south of Vitória city. This sub-unit is characterized by thick layers of marble enveloped by paragneisses.

- Sub-unit 2 is the rock assemblage of the kinzigitic complex exposed in the northern region of Espírito Santo State and eastern Minas Gerais State, particularly in the region between the Doce and Mucuri rivers. Although most of this region is not covered by geologic maps in the 1:100,000 scale or more detailed maps, the geologic sections that have been studied by Pedrosa-Soares and colaborators suggest that this sub-unit is rich in kinzigite and subordinate less aluminous paragneisses, but very poor in the other rocks referred above.

- Sub-unit 3 is exposed in the northeastern region of Minas Gerais State (north of the Mucuri River) and in the southernmost region of Bahia State. The sub-unit 3 comprises the rock assemblage of the kinzigitic complex rich in graphite gneiss and quartzite intercalations. The layers and lenses of graphite gneiss are of major economic importance because they include the most important deposits of flake graphite that have been explored and mined in South America (Faria 1997, Reis 1999, Daconti 2004).

Since the pioneering $\mathrm{Rb}-\mathrm{Sr}$ geochronological studies of Cordani (1973) the timing of the late Neoproterozoic (Brasiliano) tectono-metamorphic event recorded by the kinzigitic complex has been refined by analytical data from different isotopic methods. Siga Jr. (1986) presented the first zircon U-Pb age (590 $\pm 28 \mathrm{Ma}$ ) for the kinzigitic complex and ascribed it to the regional metamorphism.

Isotopic analysis performed by current ID-TIMS and SHRIMP methods have yielded U-Pb ages of zircon (Söllner et al. 1991, Nalini 1997, Silva et al. 2002) and monazite (Whittington et al. 2001) that dated the syncollisional stage of the Araçuaí Orogen in 
the interval of $c a .585-560 \mathrm{Ma}$. The regional foliation was imprinted in the kinzigitic complex, as well as in the Macaúbas Group, G1 and G2 suites (Fig. 1), during the syncollisional stage of the Araçuaí Orogen (Pedrosa-Soares \& Wiedemann-Leonardos 2000). The kingizitic complex reached temperatures of ca. $700^{\circ}-800^{\circ} \mathrm{C}$, at relatively low pressures (4-5 kb), during the syncollisional tectonometamorphic event, as suggested by synkinematic mineral associations and geothermometric data (Faria 1997, Uhlein et al. 1998, Pedrosa-Soares \& Wiedemann-Leonardos 2000).

The kinzigitic complex shows many evidences of distinct anatectic episodes. The foliated quartz-feldspar veins and S-type granites, synkinematic to the regional foliation, record an anatectic episode related to the syn-collisional stage (585-560 Ma). However, the granitic mobilizates free of the regional foliation, also common in the kinzigitic complex, indicate at least one late orogenic episode of partial melting. The time interval for a late anatectic event is constrained by $\mathrm{Pb}-\mathrm{Pb}$ (zircon, Basílio et al. 1998, Noce et al. 2000) and U-Pb (zircon and monazite, Whittington et al. 2001, Silva et al. 2002) ages in the interval of $c a .535-500 \mathrm{Ma}$.

Despite of the isotopic Sm-Nd studies by Celino (1999) and Daconti (2004), the sedimentation age of the kinzigitic complex has remained uncertain. These authors presented $\mathrm{Sm}-\mathrm{Nd}$ model ages in the interval 1,85-1,61 Ga for the sub-unit 3 (Jequitinhonha Complex) of the kinzigitic complex, suggesting that the sedimentary protoliths were supplied by a mixture of Paleoproterozoic and younger sources. Pedrosa-Soares \& Wiedemann-Leonardos (2001) suggested that the younger sources could be magmatic rocks formed during the rift stages of the Espinhaço (Staterian) and Macaúbas (Tonian) basins. Recently, Lima et al. (2002) presented U-Pb SHRIMP ages for the detrital zircons of the conglomerategraywacke-pelite association of the Salinas Formation. The youngest zircon grains ( $\mathrm{ca}$.600-570 Ma) were considered to be derived from the erosion of the magmatic arc of the Araçuaí Orogen.

GEOCHRONOLOGY Analytical procedures Heavymineral concentrates were obtained using standard techniques, and zircon and monazite grains were hand-picked under a binocular microscope. Zircon SHRIMP analyses were carried out at the Research School of Earth Sciences, Australian National University. Zircon grains were mounted in a 1 in. diameter epoxy disk with standard RSES zircon crystals and sectioned approximately in half. The mount surface was then polished to expose the grain interiors and photographed to obtain cathodo-luminescence (CL) images. Ion microprobe analyses were carried out using SHRIMP RG. Analytical methods and data treatment followed those described by Williams (1998) and Williams \& Meyer (1998). Common lead corrections were performed using the Cumming \& Richards (1975) model. Uncertainties reported in table 1 are given at the $1 \sigma$ level, and final ages are quoted at $95 \%$ confidence level. The data have been processed using SQUID and Isoplot/Ex software (Ludwig 1999, 2000). Monazite ID-TIMS analyses were carried out at the Geochronology Laboratory of Universidade de Brasília.

Sample description and results SAMPLE WC-11 This sample was collected from an outcrop (UTM: 359156E and 7928950N) located $c a .12 \mathrm{~km}$ east of Nova Venécia town, under the bridge of the BR-381 road over the Preto River. The outcrop displays a banded cordierite-garnet-biotite gneiss with foliation (170/20) parallel to the gneissic banding. Axis of isoclinal folds plunge to NNW (300/ 10). Quartz-feldspar veins are quite rare. The essential minerals of the light gray bands are quartz, plagioclase, cordierite, biotite, $\mathrm{K}$ - feldspar and garnet; and the accessory minerals are fibrolite (as inclusions inside cordierite), hercynite associated to magnetite, apatite, zircon and rare flakes of graphite. The mineral composition of the dark gray bands is similar to the composition of the light ones, but they show greater amounts of biotite and K-feldspar, and less or none fibrolite. Monazite was not found in this sample.

The sample yielded a small population of large $(200-300 \mu \mathrm{m})$ detrital zircons. The grains displays rounded to well preserved prismatic shapes, thus suggesting erosion from local to more distant sources. Zircon grains also display a variety of internal structures which agrees with the proposition of multiple source areas for the sediment (Fig. 2).

One spot analysis was carried out on each of the eight selected zircon crystals (Table 1 and Fig. 3). They are concordant to closely concordant and seven of them yield neoproterozoic ages. Five crystals with thin oscillatory zoning (grains 1, 5, 6, 7, 8) are typically from felsic igneous rocks. One of them has a well developed metamorphic rim (zircon 1) that was not analyzed. The mean ${ }^{207} \mathrm{~Pb} /$ ${ }^{206} \mathrm{~Pb}$ age for these five detrital zircons of magmatic origin was calculated at $631 \pm 19 \mathrm{Ma}(\mathrm{MSWD}=1.4$, Fig. 4), that agrees well with the calculated mean ${ }^{206} \mathrm{~Pb} /{ }^{238} \mathrm{U}$ at $631 \pm 11 \mathrm{Ma}$. This age is assumed as the upper age limit for the deposition of the original sediment.

Zircon 3 was excluded from age calculation in spite of $\mathrm{a}^{207} \mathrm{~Pb} /$ ${ }^{206} \mathrm{~Pb}$ age in the same range, because of its very high $\mathrm{U}$ content (2638 ppm) that could suggest a severe Pb-loss. It also lacks the oscillatory zoning that is characteristic to the other zircon grains.

Zircon 2 displays a thick zoning similar to crystals formed in mafic magmas, and has a distinct older ${ }^{207} \mathrm{~Pb} /{ }^{206} \mathrm{~Pb}$ age at $774 \pm 13$ Ma. Zircon 4 yields a paleoproterozoic age.

Despite of the small number of analyzed detrital zircons, the data suggest three sources of distinct ages for the sedimentary protoliths: two of neoproterozoic age ( $c a$. $631 \pm 19$ Ma and $774 \pm 13$ $\mathrm{Ma})$ and one of paleoproterozoic age (ca. 2104 $\pm 12 \mathrm{Ma})$.

SAMPLE WC-27 The outcrop (UTM: 328696 and 7838802) is a street cut (Bartovino Costa street), located in downtown Colatina. The rock is a banded garnet-biotite gneiss with foliation (275/30) parallel to the gneissic banding. The light gray bands are rich in quartz, K-feldspar and plagioclase, but poor in biotite and garnet. Their predominant texture is a polygonal intergrowth of quartz and feldspar, but evidence of incipient partial melting is also present (e.g., consertal boundary and micrographic texture). The dark gray bands consist of quartz, biotite, K-feldspar, plagioclase, garnet, apatite, monazite and small zircon grains. Anatectic granitic and pegmatitic veins are a common feature of the kinzigitc complex in this area, despite being relatively rare in the studied outcrop.

Monazite occurs as idiomorphic crystals, associated to biotiteapatite clusters. Only one generation of monazite was observed in this sample and it is considered to be neoformed, i.e., non-detrital, in view of the crystal shape and textural relations.

The selected single monazite crystals (300-400 $\mu \mathrm{m}$ in size) yielded discordant analyses plotting on a discordia line with an upper intercept at 530 $\pm 5 \mathrm{Ma}$ (MSWD=5.6; Table 2 and Fig. 5). A mean ${ }^{207} \mathrm{~Pb} /{ }^{206} \mathrm{~Pb}$ age for these crystals was calculated at $542 \pm 22$ $\mathrm{Ma}$, thus in agreement with the discordia age. This age is younger than the epoch of the regional metamorphism (585-560 Ma), but is useful for constraining the timing of the high temperature, late orogenic stage.

CONCLUSIONS Detrital zircon dating disclosed three sources of distinct ages for the kinzigite sample WC-11. The older one is 
Ages of sedimentation of the Kinzigitic Complex and of a late orogenic thermal episode in the Araçuai Orogen, northern Espirito Santo State, Brazil: U-PD SHRIMP and ID-TIMS data fromzircon and monazite

paleoproterozoic, supported by $\mathrm{Nd}$ model ages $\left(\mathrm{T}_{\mathrm{DM}}\right)$ for the same unit(Celino 1999, Daconti 2004). A likely source of paleoproterozoic age are the ca.2.2-2.1 Ga plutonic complexes (e.g. Juiz de Fora, Quirino, Pocrane, Itabuna, in Brazil, and the Eburnean-Kimezian complexes of the Africa counterpart) that make up a large portion of the Araçuaí Orogen basement. The age of $774 \pm 13 \mathrm{Ma}$, yielded by a detrital grain probably derived from a mafic rock, is very close to an age of $792 \pm 2 \mathrm{Ma}$ obtained for a pre-collisional tonalitic gneiss of the Ribeira Orogen (Heilbron \& Machado 2003).

Despite the high grade metamorphism, the youngest zircon
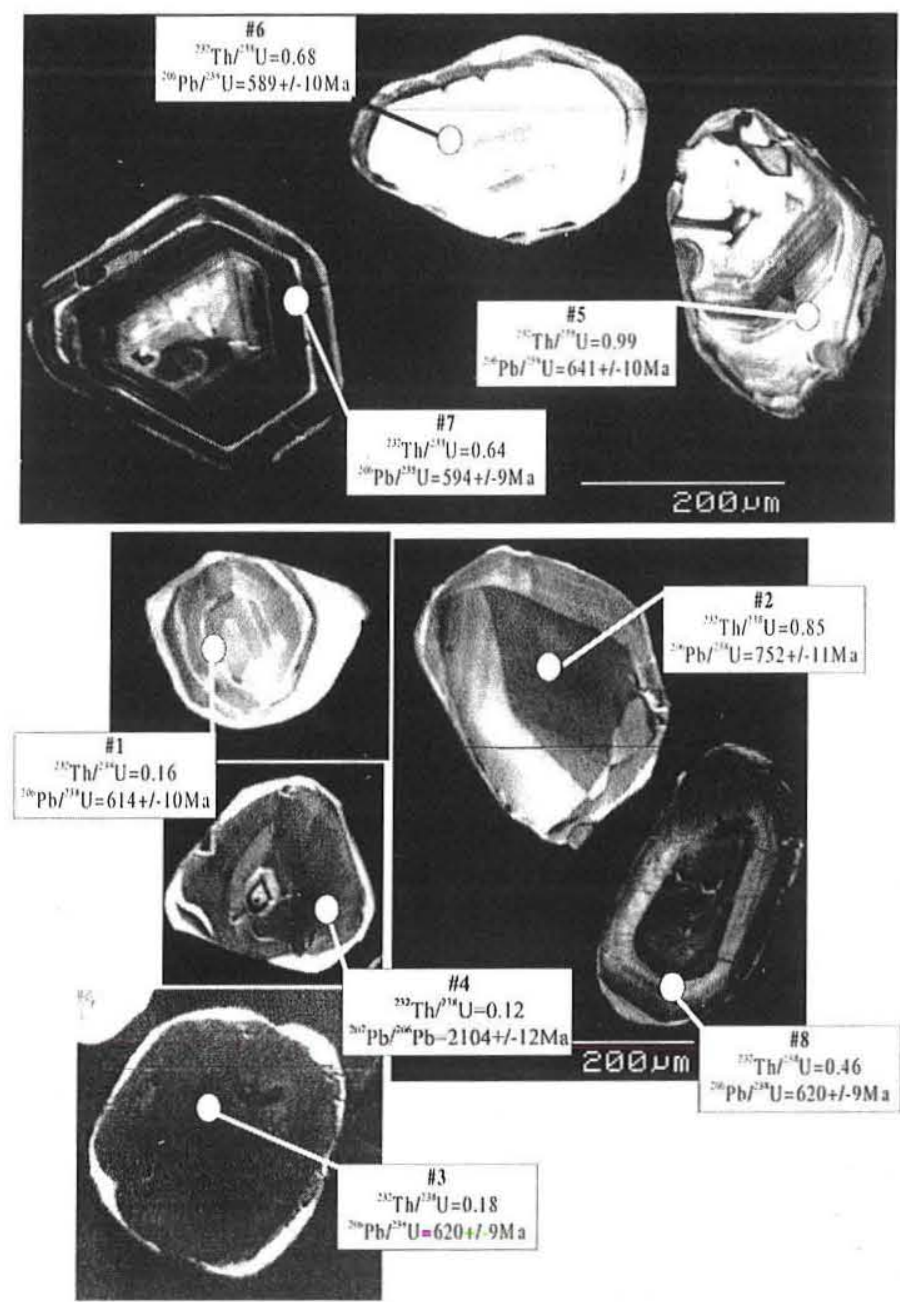

Figure 2 - Cathodo-luminiscence images of zircon grains from the sample WC-11, displaying their morphology and internal features, $T h / U$ ratios and $\mathrm{Pb}-U$ ages. Circle indicates analyzed spot.

Table 1 -Summary of SHRIMP U-Pb zircon data for sample WC-11.

\begin{tabular}{|c|c|c|c|c|c|c|c|c|c|c|c|c|c|c|c|c|c|}
\hline $\begin{array}{l}\text { Grain } \\
\text { spot }\end{array}$ & $\begin{array}{c}\% \% \\
{ }^{206} \mathrm{~Pb}_{\mathrm{c}}\end{array}$ & $\begin{array}{c}\mathrm{U} \\
(\mathrm{ppm})\end{array}$ & $\begin{array}{c}\text { Th } \\
\text { (ppm) }\end{array}$ & $\begin{array}{l}{ }^{232} \mathrm{Th} \\
{ }^{238} \mathrm{U}\end{array}$ & $\begin{array}{l}{ }^{206} \mathrm{~Pb}^{*} \\
\text { (ppm) }\end{array}$ & & & 207 & & $\begin{array}{c}\% \\
\text { Discordant }\end{array}$ & $\begin{array}{c}(1) \\
{ }^{207} \mathrm{~Pb}^{*} \\
{ }^{206} \mathrm{~Pb}^{*}\end{array}$ & $\pm \%$ & $\begin{array}{c}{ }^{(1)} \\
{ }^{207} \mathrm{~Pb}^{*} \\
{ }^{235} \mathrm{U}\end{array}$ & $\pm \%$ & $\begin{array}{c}{ }^{(1)} \\
{ }^{206} \mathrm{~Pb}^{\circ} \\
{ }^{238} \mathrm{U}\end{array}$ & $\pm \%$ & $\begin{array}{c}\text { Error } \\
\text { correction }\end{array}$ \\
\hline 1.1 & 0.07 & 232 & 36 & 0.16 & 19.9 & 614.3 & \pm 9.5 & 618 & \pm 25 & I & 0.06039 & 1.1 & 0.833 & 2.0 & 0.1000 & 1.6 & 0.816 \\
\hline 2.1 & 0.00 & 401 & 332 & 0.85 & 42.7 & 752 & \pm 1 & 774 & \pm 13 & 3 & 0.06499 & 0.62 & 1.108 & 1.6 & 0.1237 & 1.5 & 0.924 \\
\hline 3.1 & $\cdots$ & 2638 & 456 & 0.18 & 229 & 620.0 & \pm 8.8 & 55.3 & \pm 5.4 & 5 & 46 & 0.25 & 0.855 & 1.5 & 0.1009 & 1.5 & 6 \\
\hline 4.1 & 0.01 & 656 & 78 & 0.12 & 215 & 2,086 & \pm 32 & 2,104 & \pm 12 & 1 & 0.13047 & 0.71 & 6.87 & 1.9 & 0.3820 & 1.8 & 0.930 \\
\hline 5.1 & 0.02 & 93 & 89 & 0.99 & 8.37 & 640.8 & \pm 9.8 & 707 & \pm 4 & 9 & 0.0630 & 2.1 & 0.907 & 2.6 & 0.1045 & 1.6 & 0.610 \\
\hline 6.1 & 0.06 & 148 & 97 & 0.68 & 12.2 & 589.3 & \pm 9.8 & 600 & \pm 37 & 2 & 0.0599 & 1.7 & 0.791 & 2.4 & 0.0957 & 1.7 & 0.716 \\
\hline 7.1 & 0.05 & 942 & 583 & 0.64 & 78.2 & 593.9 & \pm 8.6 & 645 & \pm 11 & 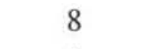 & 0.06115 & 0.53 & 0.814 & 1.6 & 0.0965 & 1.5 & 0.944 \\
\hline 8.1 & 0.02 & 1706 & 763 & 0.46 & 148 & 619.6 & \pm 9.1 & 626.9 & \pm 6.9 & 1 & 0.06065 & 0.32 & 0.844 & 1.6 & 0.1009 & 1.5 & 0.979 \\
\hline
\end{tabular}

Errors are $1 \sigma ; \mathrm{Pb}_{c}$ and $\mathrm{Pb}^{*}$ indicate the common and radiogenic portions, respectively. Error in standard calibration was $0.47 \%$ (not included in above errors but required when comparing data from different mounts). (1) - Common $\mathrm{Pb}$ corrected using measured ${ }^{204} \mathrm{~Pb}$. 
grains show well-preserved magmatic cores, with typically igneous $\mathrm{Th} / \mathrm{U}$ ratios, and very thin metamorphic rims. The age interval yielded by these magmatic cores ( $\mathrm{ca}$. 640 to $589 \mathrm{Ma}$ ) are in good

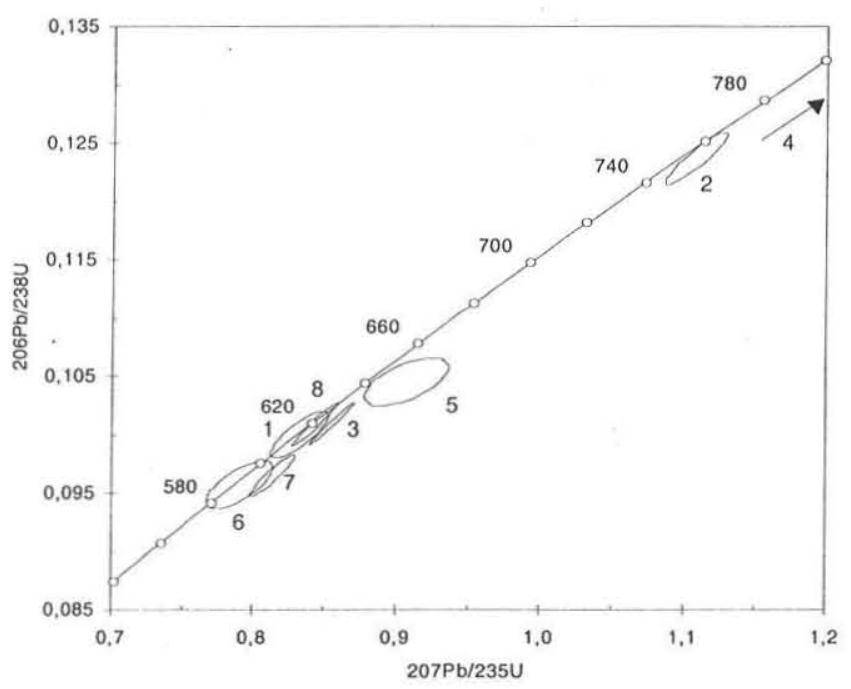

Figure 3 -Concordia diagram of zircon analyses from kinzigite WC-11. Data-point error ellipses are 68,3\% confidence level.

Table 2 - Summary of U-Pb monazite data for sample WC-27. agreement with the $\mathrm{U}-\mathrm{Pb}$ ages that limit the precollisioanl stage (ca. 630-585 Ma) of the Araçuaí Orogen. The mean ${ }^{207} \mathrm{~Pb} /{ }^{06} \mathrm{~Pb}$ age of $631 \pm 19 \mathrm{Ma}$ for these youngest zircon grains provides a maximum depositional age for the sedimentary protoliths of the kinzigitic complex. As a result of this unit had been affected by the syncollisional tectono-metamorphic event (585-560 Ma), it can be

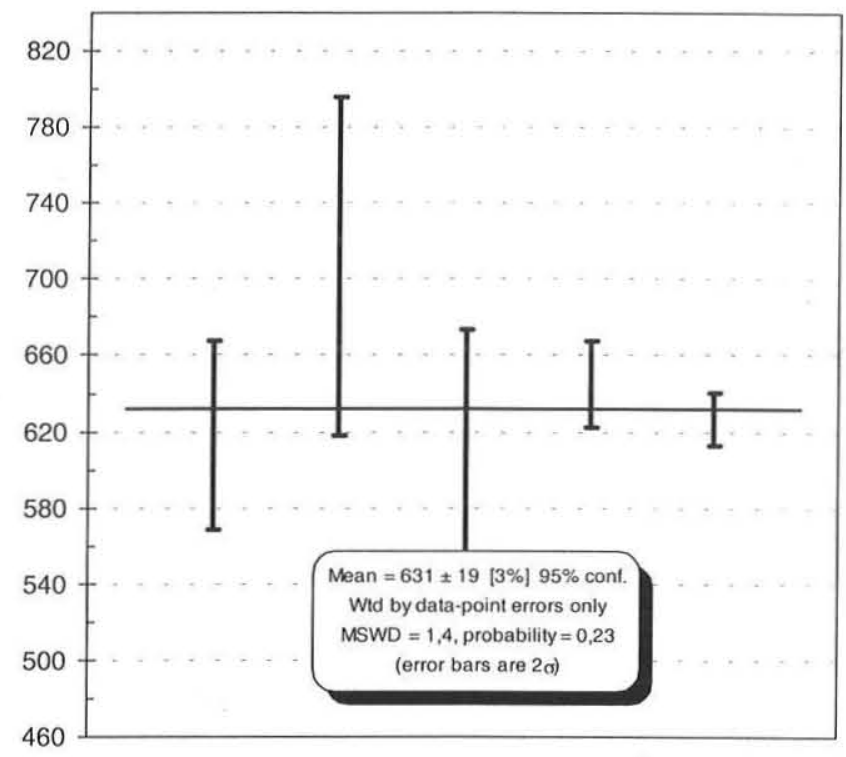

Figure $4-$ Mean ${ }^{207} \mathrm{~Pb}{ }^{06} \mathrm{~Pb}$ ages for zircon crystals 1, 5, 6, 7, and 8.

\begin{tabular}{|c|c|c|c|c|c|c|c|c|c|c|c|c|c|c|c|c|}
\hline $\begin{array}{l}2 \\
n\end{array}$ & $\begin{array}{l}\text { Size } \\
(\mathrm{mg})\end{array}$ & $\begin{array}{c}\mathrm{U} \\
\mathrm{ppm}\end{array}$ & $\begin{array}{c}\mathrm{Pb} \\
\mathrm{ppm}\end{array}$ & $\begin{array}{c}\text { Th } \\
\mathrm{ppm}\end{array}$ & $\mathrm{Th} / \mathrm{U}$ & $\begin{array}{c}{ }^{206} \mathrm{~Pb} \\
{ }^{204} \mathrm{~Pb} \\
\text { obs }\end{array}$ & $\begin{array}{l}{ }^{207} \mathrm{~Pb}^{*} \\
{ }^{2.35} \mathrm{U}\end{array}$ & $\begin{array}{l}\text { Error } \\
(\%)\end{array}$ & $\begin{array}{l}{ }^{206} \mathrm{~Pb}^{*} \\
p^{2.38} \mathrm{U}\end{array}$ & $\begin{array}{l}\text { Error } \\
(\%)\end{array}$ & $\begin{array}{l}\text { Cor. Coef. } \\
\text { rho }\end{array}$ & $\begin{array}{l}{ }^{207} \mathrm{~Pb}^{\circ} \\
\rho^{206} \mathrm{~Pb}^{*}\end{array}$ & $\pm \%$ & $\begin{array}{c}{ }^{206} \mathrm{~Pb} \\
{ }^{238} \mathrm{U} \\
\text { Age(Ma) }\end{array}$ & $\begin{array}{c}{ }^{207} \mathrm{~Pb} \\
{ }^{235} \mathrm{U} \\
\text { Age }(\mathrm{Ma})\end{array}$ & $\begin{array}{c}{ }^{207} \mathrm{~Pb} \\
/^{206} \mathrm{~Pb} \\
\mathrm{Age}(\mathrm{Ma})\end{array}$ \\
\hline & 0.234 & 4337 & 290 & 31.42 & 0.0072 & 5,244 & 0.121836 & 0.376 & 0.015093 & 0.37 & 0.9 & 0.058546 & 0.0662 & 97 & 117 & 550 \\
\hline & 0.081 & 2336 & 918 & 39.22 & 0.0168 & 044 & 0.498275 & 1 & 5 & 0.135 & 3 & 58068 & 36 & 389 & 411 & 532 \\
\hline & 0.1 & 3741 & 298 & 31.77 & 0.0085 & 4,795 & 0.153996 & 0.181 & 0.019134 & 0.177 & 0.980425 & 0.05837 & 0.0357 & 122 & 145 & 544 \\
\hline
\end{tabular}

Figure 5-Concordia diagram of monazite analyses from kinzigite $W C-27$.

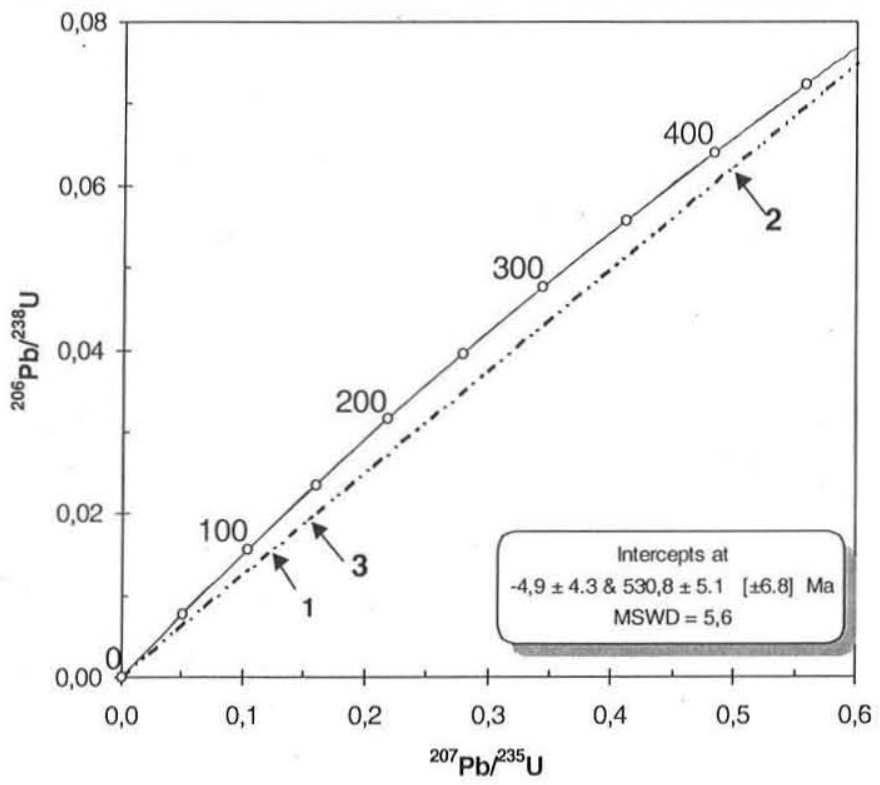

assumed that the sedimentation of the kinzigitic protoliths took place between $\mathrm{ca}$. 631 and $585 \mathrm{Ma}$. Therefore the isotopic data indicate that the kinzigitic complex was deposited during the precollisional stage of the Araçuaí Orogen, contemporaneously to the build up of the calc-alkaline magmatic arc formed in response to an eastward subduction of oceanic lithosphere (Pedrosa-Soares et al. 2001). The kinzigitic complex lies to the east of the present position of the magmatic arc, what points to a back-arc basin as the most reliable tectonic setting for the deposition of the kinzigitic rocks.

The age of monazite at ca. $530 \mathrm{Ma}$ is younger than the syncollisional tectono-metamorphic event of the Araçuaí Orogen. However, as before emphasized, the kinzigitic complex shows many evidences of partial melting postkinematic to the regional foliation. Furthermore, this late orogenic thermal event has been dated in the interval of 535-500 Ma. Thus, we suggest that the monazite age indicate the epoch of a late orogenic thermal episode, probably related to the onset of the gravitational collapse of the Araçuaí Orogen.

Acknowledgements Funding for geochronological analyses was provided by FAPEMIG (Fundação de Amparo à Pesquisa de Minas Gerais) to C.M. Noce. Field work and sample preparation 
Ages of sedimentation of the Kinzigitic Complex and of a late orogenic thermal episode in the Araçuai Orogen, northern Espirito Santo State, Brazil: U-Pb SHRIMP and ID-TIMS data fromzircon and monazite

were supported by grants from CNPq to A. C. Pedrosa Soares and Sílvia Medeiros. Márcio Pimentel and Elton Dantas provided the facilities in the Geochronological Laboratory of Brasília. To the RBG referees for suggestions to the manuscript.

\section{References}

Basílio M.S., Dussin I.A., Pedrosa-Soares A.C., Jordt-Evangelista H., Macambira M., Voll E., Pimenta V.B. 1998. Gênese dos depósitos de alexandrita de Malacacheta, Minas Gerais: evidências geológicas e geocronológicas. In: SBG, Congr. Bras. Geol., 40, Anais, p. 281.

Celino J.J. 1999. Variação composicional em suítes de granitóides neoproterozóicos e sua implicação na evolução do Orógeno Araçuaí (Brasil)-Oeste Congolês (África). Tese de Doutorado, Instituto de Geociências, Universidade de Brasília, 266 p.

Cordani U.G. 1973. Evolução Geotectônica da Região Costeira do Brasil, entre Salvador e Vitória. Tese de Livre Docência, Instituto de Geociências, Universidade de São Paulo, 98 p.

Cordani U.G., Sato K., Teixeira W., Tassinari C.C.G., Basei M.A.S. 2000. Crustal evolution of the South American Plataform. In: U.G. Cordani, E.J. Milani, A. Thomaz Filho, D.A. Campos (eds) Tectonic Evolution of South America,. $31^{\text {st }}$ International Geological Congress, pp.: $19-40$

Daconti B.C. 2004. Contexto geológico, controle e correlação regional das mineralizações de grafita da região de Almenara, Província Grafítica do Nordeste de Minas Gerais. Dissertação de Mestrado, Instituto de Geociências, Universidade Federal de Minas Gerais, 110 p.

Faria L.F. de. 1997. Controle e tipologia de mineralizações de grafita flake do nordeste de Minas Gerais e sul da Bahia: uma abordagem regional. Dissertação de Mestrado, Instituto de Geociências, Universidade Federal de Minas Gerais, 102p.

Foster G., Kinny P., Vance D., Prince C., Harris N. 2000. The significance of monazite $\mathrm{U}-\mathrm{Th}-\mathrm{Pb}$ age data in metamorphic assemblages; a combined study of monazite and garnet chronometry. Earth Planet. Sci. Lett., 181:327-340.

Heilbron M. \& Machado N. 2003. Timing of terrane accretion in the Neoproterozoic-Eopaleozoic Ribeira Orogen (SE Brazil). In: CBPMIRD, South Am. Symp. Isotope Geol., 4, Short Papers, p. 182-185.

Heilbron M., Pedrosa-Soares A.C., Campos-Neto M., Silva L.C., Trouw R., Janasi V. 2004. A Província Mantiqueira. In: V. Mantesso, A Bartorelli, C.D.R. Carneiro, B.B. Brito-Neves (eds) Geologia do Continente Sul-Americano: Evolução da Obra de Fernando Flávio Marques de Almeida.Beca Produções Culturais Ltda, São Paulo, p. 203-235

Lima S.A.A., Martins Neto M.A., Pedrosa-Soares A.C., Cordani U.G., Nutman A. 2002. A Formação Salinas na área-tipo, NE de Minas Gerais: Uma proposta de revisão da estratigrafia da Faixa Araçuaí com base em evidências sedimentares, metamórficas e idades U-Pb SHRIMP. Revi. Bras. Geoc., 32:491-500.

Ludwig K.R. 1999. User's Manual for Isoplot/Ex version 2.05, A geochronological toolkit for Microsoft Excel. Berkeley Geochronology Center, Special Publication $N^{\circ}$ la, 48p.

Ludwig K.R. 2000. SQUID 1.00, A User's Manual; Berkeley Geochronology Center, Special Publication, $N^{\circ} 2$, CA. 18p.

Mehnert K.R. 1968. Migmatites and the Origin of Granitic Rocks. Elsevier, Amsterdan, $405 \mathrm{pp}$.

Nelson D.R. 2001. An assessment of the determination of depositional ages for precambrian clastic sedimentary rocks by U-Pb dating of detrital zircons. Sedim. Geol., 141-142:37-60.
Nalini H. A. 1997. Caractérization des suites magmatiques néoprotérozoíques de la région de Conselheiro Pena et Galiléia, Minas Gerais, Brésil. Tese de Doutorado, École Nationale Superière des Mines de Saint Etienne, France, 237 p.

Noce C. M., Macambira M. J. B., Pedrosa-Soares A. C. 2000. Chronology of Neoproterozoic-Cambrian granitic magmatism in the Araçuaí Belt, Eastern Brazil, based on single zircon evaporation dating. Rev. Bras. Ceoc., 30:25-29.

Pedrosa-Soares A.C. \& Wiedemann-Leonardos C.M. 2000. Evolution of the Araçuaí Belt and its connection to the Ribeira Belt, Eastern Brazil. In: U.G. Cordani, E.J. Milani, A. Thomaz Filho, D.A. Campos (eds) Tectonic Evolution of South America, $31^{\mathrm{N}}$ Intern. Geol. Cong., pp.: 265-285

Pedrosa-Soares A.C., Noce C. M., Wiedemann C., Pinto C.P. 2001.The Araçuaí-West-Congo Orogen in Brazil: an overview of a confined orogen formed during Gondwanaland assembly. Prec. Res., 110:307-323.

Pinto C.P., Drumond J.B.V., Féboli W.L. (coords.) 2002. Projeto Leste: geologia - nota explicativa do mapa geológico integrado-etapa 1 , folhas SE.24-V, SE.23-Z, SE.24-Y (partes) escala 1:500.000. SEME/ COMIG/MME/CPRM, Belo Horizonte, CD-ROM, 181 pp.

Reis L.B. 1999. Estudo de mineralizações de grafita no extremo nordeste de Minas Gerais. Dissertação de Mestrado, Instituto de Geociências, Universidade Federal de Minas Gerais, 87p.

Siga Jr. O. 1986. A evolução geocronológica da porção nordeste de Minas Gerais, com base em interpretações geocronológicas. Dissertação de Mestrado, IG-USP, 140 p.

Silva L.C. da, Armstrong R., Noce C.M., Pimentel M.M., Pedrosa-Soares A.C., Leite C., Vieira V.S., Paes V. 2002. Reavaliação U-Pb SHRIMP em terrenos pré-cambrianos brasileiros. Parte II: Orógeno Araçuaí, Cinturão-Mineiro e Cráton São Francisco Meridional. Revi. Bras: Geoc., 32:513-528.

Söllner F, Lammerer B., Weber-Diefenbach, K. 1991. Dic Krustenentwicklung in der Küstenregion Nördlich von Rio de Janeiro/ Brasilien. Münchner Geologishe Hefte, 4:1-100.

Uhlein A., Egydio-Silva M., Bouchez J.L., Vauchez A.,1998. The Rubim pluton (Minas Gerais, Brazil): a petrostructural and magnetic fabric study. J. South Am. Earth Sci., 11:179-189.

Williams I.S. 1998. U-Th-Pb Geochronology by Ion Microprobe. In: M.A McKibben, W.C Sahnks III, W.I Ridley (eds) Applications of microanalytical techniques to understanding mineralizing processes Reviews in Economic Geology, 7.

Williams I.S. and Meyer C. 1998. U-Pb geochronology of zircons from lunar breccia 73217 using a sensitive high mass-resolution ion microprobe. J. Geoph. Res., 89:B525-B534.

Whittington A.G., Connelly J., Pedrosa-Soares A.C., Marshak S., Alkmim F.F. 2001. Collapse and melting in a confined orogenic belt: preliminary results from the neoproterozoic Araçuaí belt of eastern Brazil. In: AGU, Meeting, v. 82., p.1181-1182.

Manuscrito A-1485

Recebido em 17 de fevereiro de 2004

Revisão dos autores em 28 de setembro de 2004 Revisão aceita em 10 de outubro de 2004 